\title{
Genetic Mechanisms in Aspirin-Exacerbated Respiratory Disease
}

\author{
Nami Shrestha Palikhe, Seung-Hyun Kim, Hyun Jung Jin, Eui-Kyung Hwang, \\ Young Hee Nam, and Hae-Sim Park
}

Department of Allergy and Clinical Immunology, Ajou University School of Medicine, San-5, Woncheondong, Youngtonggu, Suwon 442-721, Republic of Korea

Correspondence should be addressed to Hae-Sim Park, hspark@ajou.ac.kr

Received 12 April 2011; Accepted 14 June 2011

Academic Editor: Luis M. Teran

Copyright () 2012 Nami Shrestha Palikhe et al. This is an open access article distributed under the Creative Commons Attribution License, which permits unrestricted use, distribution, and reproduction in any medium, provided the original work is properly cited.

\begin{abstract}
Aspirin-exacerbated respiratory disease (AERD) refers to the development of bronchoconstriction in asthmatics following the exposure to aspirin or other nonsteroidal anti-inflammatory drugs. The key pathogenic mechanisms associated with AERD are the overproduction of cysteinyl leukotrienes (CysLTs) and increased CysLTR1 expression in the airway mucosa and decreased lipoxin and PGE2 synthesis. Genetic studies have suggested a role for variability of genes in disease susceptibility and the response to medication. Potential genetic biomarkers contributing to the AERD phenotype include HLA-DPB1, LTC4S, ALOX5, CYSLT, PGE2, TBXA2R, TBX21, MS4A2, IL10, ACE, IL13, KIF3A, SLC22A2, CEP68, PTGER, and CRTH2 and a four-locus SNP set composed of $B 2 A D R, C C R 3, C y s L T R 1$, and FCER1B. Future areas of investigation need to focus on comprehensive approaches to identifying biomarkers for early diagnosis.
\end{abstract}

\section{Introduction}

Aspirin-exacerbated respiratory disease (AERD) refers to the development of bronchoconstriction in asthmatics following the ingestion of aspirin or other nonsteroidal antiinflammatory drugs. It is defined by a clinical syndrome associated with moderate-to-severe asthma and eosinophil inflammation in the upper and lower airways, resulting in chronic rhinosinusitis and asthma [1]. Additionally, the airways of AERD show epithelial disruption, cytokine production, and the upregulation of inflammatory molecules [2]. The prevalence of aspirin hypersensitivity in the general population ranges from 0.6 to $2.5 \%$ and is higher in asthmatics [3].

The dysregulation of arachidonic acid metabolism also accounts for the susceptibility to AERD. Metabolites involved are prostaglandins (PGs), leukotrienes (LTs), and thromboxane (TBX). Inhibition of COXs by acetyl salicylic acid (ASA) in the respiratory tract alters arachidonic acid metabolism, leading to a reduction in PGE2. This may increase AERD susceptibility by overproduction of CysLTs $[4,5]$. The lipoxygenase (LOX) pathway produces the leukotrienes LTA4, LTB4, and LTC4 as metabolites. 15-lipoxygenase (15-LO) is one of the LOX family members and catalyses the conversion of arachidonic acid to 15-hydroxyperoxyeicosatetranoic acid (15-HPETE). 15-hydroxyeicosatetranoic (15-HETE), a more stable derivative of 15-HPETE, is another important product, which acts as an anti-inflammatory mediator and functional antagonist of LTs [6]. Further products of 15HPETE include eoxins (EXs) EXA4 and 15-HETE can be conjugated with glutathione, leading to the formation of EXC4, EXD4, and EXE4. AERD has also been correlated with increased CysLT receptors: CysLTR1 and CysLTR2 [79]. The third CysLT receptor, the G protein-coupled receptor 17 (GPR17) [9], is located at an intermediate phylogenetic position between two distinct receptor families: the purinergic receptor (P2Y) and CysLT receptor for extracellular nucleotides and CysLTs, respectively, [10]. Overexpression of CysLTR1 was detected in the nasal mucosa of patients with AERD, compared with aspirin-tolerant asthma (ATA) [11]. Considering the pathogenic mechanism of AERD, various genetic markers have been suggested in various ethnic groups and are summarized in this paper.

\section{Key Results Regarding Genetic Mechanisms}

2.1. Leukotriene Related Genes and Their Mechanism. Based on evidence showing a close association of leukotrienes and 
AERD, initial research was performed on the association between LTC4S $-444 \mathrm{~A}>\mathrm{C}$ promoter polymorphism and AERD. In the population investigated (Polish), the $\mathrm{C}$ allele was identified as a risk factor; however, this finding was not replicated in Japanese, American, or Korean populations [12-15]. SNPs of 5-lipoxygenase; ALOX5 at $-1708 \mathrm{G}>\mathrm{A}$, $21 \mathrm{C}>\mathrm{T}, 270 \mathrm{G}>\mathrm{A}$, and $1728 \mathrm{G}>\mathrm{A}$ and ALOX5 activating protein $(A L O X 5 A P, 218 \mathrm{~A}>\mathrm{G})$ were studied in a Korean population where it was discovered that the haplotype ALOX5 ht1 [G-C-G-A] was significantly higher in AERD than in ATA, suggesting a possible contribution of ALOX5 in AERD [16]. We identified three SNPs $(-634 \mathrm{C}>\mathrm{T}$, $-475 \mathrm{~A}>\mathrm{C}$, and $-336 \mathrm{~A}>\mathrm{G}$ ) in the promoter region of CysLTR1, and mutant variants of these SNPs were associated with the AERD phenotype [17]. The mutant variants showed higher promoter activity, suggesting that these polymorphisms may modulate CysLTR1 expression increasing AERD susceptibility. In the case of CysLTR2, the frequencies of minor alleles for $-819 \mathrm{~T}>\mathrm{G}, 2078 \mathrm{C}>\mathrm{T}$, and $2534 \mathrm{~A}>\mathrm{G}$ were significantly higher in the AERD group [18] when compared with ATA.

2.2. Cyclooxygenase, Prostanoid, and Human Leukocyte Antigen Markers and Related Mechanisms. It has been suggested that AERD is associated with both COX1 and COX2. Aspirin inhibits both of these proteins, with a greater effect on COX1. COX2 expression was downregulated in nasal polyps collected from AERD patients [19]. Decreased production of prostaglandin E2 (PGE2) by nasal epithelial cells of AERD has been observed [20]. PGE2 production in airway smooth muscle cells has been shown to downregulate COX2 mRNA expression [21]. Two SNPs of TBXA2R, $-4684 \mathrm{~T}>\mathrm{C}$, and $+795 \mathrm{~T}>\mathrm{C}$, were shown to be associated with the phenotype of AERD in a Korean population [22, 23]. The prostaglandin E2 receptor subtype 2 gene (PTGER2) was associated with the risk of AERD by decreasing the level of transcription, resulting in a reduction of the "PGE2 braking" mechanism of inflammation and involvement in the molecular mechanism underlying AERD in the Japanese population [24]. A further report in the Korean population showed that prostaglandin E2 receptor subtype 3 (PTGER3) may be an important genetic factor for aspirin intolerance in Korean asthmatics [25]. The human leukocyte antigen (HLA) allele $D P B 1^{*} 0301$ was identified as a strong marker for AERD, because patients with this allele showed typical characteristics of AERD including a decreased forced expiratory volume in $1 \mathrm{~s}\left(\mathrm{FEV}_{1}\right)$ and increased prevalence of rhinosinusitis with nasal polyps [26], as previously noted in a Polish population [27].

2.3. Eosinophil-Related Genetic Mechanisms. Eosinophil infiltration into the upper and lower airways is a key feature of AERD. Increased numbers of eosinophils and mast cells have been observed in the bronchial mucosa of AERD [28, 29]. Recent studies demonstrated that the chemoattractant receptor molecule expressed in Th2 cells, the CRTH2 -466T > C polymorphism, could increase serum and cellular eotaxin2 production by lowering CRTH2 expression, leading to eosinophilic infiltration in AERD patients [30]. A further study indicated that the chemokine CC motif receptor (CCR3) may be related to eosinophil migration. The CCR3 $-520 \mathrm{~T}>\mathrm{C}$ was significantly associated with AERD patients where mRNA expression was also significantly increased after ASA provocation [31]. IL-13 polymorphisms at $-1510 \mathrm{~A}>\mathrm{C}$ and $1055 \mathrm{C}>\mathrm{T}$ are associated with the development of rhinosinusitis in AERD patients. IL-13 Arg110Gln may be associated with an increased eosinophil count and eotaxin1 level, leading to an increase in eosinophilic inflammation in the upper and lower airways of patients with AERD [32] (Table 1).

2.4. AERD and Viral Infection. Szczeklik has hypothesized that AERD develops as the result of chronic viral infection [33]. Viral respiratory infections have been suggested to contribute to allergic sensitization, leading to the development of asthma and in subjects with established asthma; they are known to exacerbate allergic disease [34]. Aspirin hypersensitivity is diminished in some AERD patients during acyclovir treatment of herpes simplex infection [35]. Moreover, elevated levels of IgG4, derived from chronic antigenic stimulation of viral origin, have been noted in AERD patients [36]. A further study investigating the exacerbation of AERD with airway infection of respiratory syncytial virus was reported [37]. Recently, a study indicated that the polymorphisms in the Toll-like receptor 3 (TLR3) gene, TLR3 $-299698 \mathrm{G}>\mathrm{T}$ and $293391 \mathrm{G}>\mathrm{A}$, were associated with the AERD phenotype. TLR3 recognizes dsRNA, activates nuclear factors, and increases interferon-gamma, which is a signal to other cells and increases antiviral defenses. As functional deterioration of TLR3 can predispose individuals to increased susceptibility to viral infections, the detection of TLR3 polymorphisms may be informative for risk assessment in AERD susceptibility [38]. The suggested mechanism is that specific cytotoxic lymphocytes are produced in response to viral infection. Activity of these lymphocytes is suppressed by PGE2, which is produced by pulmonary alveolar macrophages. If PGE2 levels are decreased, cytotoxic reactions are preceded by COX inhibitors and cytotoxic lymphocyte-mediated attacks lead to the destruction of virus affected cells in the respiratory tract. Reactive oxygen species, toxic metabolites, and mediators released then precipitate asthma attacks.

2.5. Other Suggested Mechanisms. The ubiquitin-proteasome pathway-related gene (UBE3C) has been recently studied in a Korean population and indicated that rs3802122 and rs6979947 is associated with AERD [39]. A further study indicated that the kinesin family number $3 \mathrm{~A}$ (KIF3A) gene and its polymorphism might have an effect on AERD, because rs3756775 revealed a significant association with the percentage decline in $\mathrm{FEV}_{1}$ after aspirin provocation [40]. Recently, the genome-wide methylation profile of nasal polyps showed that genes involved in lymphocyte proliferation, cell proliferation, leukocyte activation, cytokine biosynthesis, immune responses, inflammation, and immunoglobulin binding were hypomethylated. In the arachidonic pathways, PGDS, ALOX5AP, and LTB4R were 
TABLE 1: Genetic mechanisms of AERD.

\begin{tabular}{|c|c|c|c|}
\hline Gene name & SNPs & Clinical phenotype & Mechanism \\
\hline \multicolumn{4}{|c|}{ Leukotriene synthesis } \\
\hline LTC4S & $-444 \mathrm{~A}>\mathrm{C}$ & $\begin{array}{l}\mathrm{C} \text { allele had high genotype } \\
\text { frequency compared with A allele }\end{array}$ & $\begin{array}{l}\mathrm{C} \text { allele may be the risk allele due } \\
\text { to overproduction of CysLTs }\end{array}$ \\
\hline ALOX5 & $\begin{array}{l}-1708 \mathrm{G}>\mathrm{A}, 21 \mathrm{C}>\mathrm{T} \\
270 \mathrm{G}>\mathrm{A}, 1728 \mathrm{G}>\mathrm{A}\end{array}$ & $\begin{array}{l}\text { ALOX5 ht1(GCGA) had higher } \\
\text { haplotype frequency }\end{array}$ & $\begin{array}{l}\text { ALOX5 ht1(GCGA) may be the } \\
\text { risk haplotype }\end{array}$ \\
\hline CYSLTR1 & $\begin{array}{c}-634 \mathrm{C}>\mathrm{T},-475 \mathrm{~A}>\mathrm{C} \\
-336 \mathrm{~A}>\mathrm{G}\end{array}$ & $\begin{array}{l}\text { ht } 2 \text { (TCG) showed higher } \\
\text { frequency in AERD and higher } \\
\text { promoter activity }\end{array}$ & $\begin{array}{l}\text { Higher CysLTR } 1 \text { mRNA } \\
\text { expression may be responsible } \\
\text { for pathogenesis }\end{array}$ \\
\hline CYSLTR2 & $-819 \mathrm{~T}>\mathrm{C}$ & $\begin{array}{l}\text { the frequencies of rare allele were } \\
\text { increased in AERD and fall in } \\
\text { FEV1 after aspirin provocation }\end{array}$ & Elevation of CysLTs production \\
\hline \multicolumn{4}{|c|}{ COX/PG pathway and HLA allele } \\
\hline PTGER & rs7543182 rs959 & $\begin{array}{l}\text { These two polymorphisms } \\
\text { retained their susceptibility to } \\
\text { aspirin intolerance in first and } \\
\text { second cohorts }\end{array}$ & $\begin{array}{l}\text { PTGER3 might play a significant } \\
\text { role in aspirin hypersensitivity }\end{array}$ \\
\hline TBXA2R & $+795 \mathrm{~T}>\mathrm{C}$ & $\begin{array}{l}\text { AERD patients with homozygous } \\
+795 \text { C allele had a greater } \\
\text { percent fall in FEV1 after aspirin } \\
\text { exposure compared with } \\
\text { TBXA2R+795 CT or TT } \\
\text { genotypes. }\end{array}$ & $\begin{array}{l}\text { TBXA2R }+795 \mathrm{~T}>\mathrm{C} \text { may } \\
\text { increase bronchoconstrictive } \\
\text { response to ASA }\end{array}$ \\
\hline HLA & $\mathrm{DPB} 1^{*} 0301$ & $\begin{array}{l}\text { Patients with DPB } 1 * 0301 \text { allele } \\
\text { had higher prevalence of } \\
\text { Rhino-sinusitis and lower FEV1 } \\
\text { values. }\end{array}$ & $\begin{array}{l}\text { HLA markers may be important } \\
\text { for LTRA therapy }\end{array}$ \\
\hline Gene name & SNPs & Clinical Phenotype & Mechanism \\
\hline \multicolumn{4}{|c|}{ Eosinophil activation } \\
\hline CRTH2 & $-466 \mathrm{~T}>\mathrm{C}$ & $\begin{array}{l}-466 \mathrm{~T} \text { allele had higher } \\
\text { frequency in AERD and } \\
\text { increased serum, cellular } \\
\text { eotaxin- } 2 \text { production and lower } \\
\text { mRNA expression }\end{array}$ & $\begin{array}{l}-466 \mathrm{~T} \text { allele may be the risk } \\
\text { allele by activation of eosinophils }\end{array}$ \\
\hline CCR3 & $-520 \mathrm{~T}>\mathrm{C}$ & $\begin{array}{l}\text { The frequencies of rare } \\
\text { genotypes were higher in AERD } \\
\text { and - } 520 \text { G allele showed higher } \\
\text { promoter activity }\end{array}$ & $\begin{array}{l}\text { Higher mRNA expression of } \\
\text { CCR3 may cause eosinophil } \\
\text { activation }\end{array}$ \\
\hline IL 13 & $\begin{array}{c}\text { 1510A > C, 1055C > T, } \\
\text { Arg110Gln }\end{array}$ & $\begin{array}{l}\text { Increase eotaxin-1 and } \\
\text { peripheral eosinophil count }\end{array}$ & Eosinophil activation may occur \\
\hline \multicolumn{4}{|l|}{ Mast cell activation } \\
\hline FCERIG & $-237 \mathrm{~A}>\mathrm{G}-344 \mathrm{C}>\mathrm{T}$ & $\begin{array}{l}\text { AA type of }-237 \mathrm{~A}>\mathrm{G} \text { showed } \\
\text { high serum total IgE; CC/CT of } \\
-344 \mathrm{C} / \mathrm{T} \text { had higher SEA }\end{array}$ & Mast cells may be activated \\
\hline MS4A2R & E237G & $\begin{array}{l}\text { FcER } 1 \mathrm{~b}-109 \mathrm{~T} \text { allele had higher } \\
\text { frequency and high promoter } \\
\text { activity }\end{array}$ & $\begin{array}{l}\text { Increased mRNA expression of } \\
-109 \mathrm{~T} \text { allele may cause mast cell } \\
\text { activation mediated by MS4A2R } \\
\text { receptor }\end{array}$ \\
\hline \multicolumn{4}{|l|}{ Other mechanisms } \\
\hline IL- 10 and TGF- $\beta 1$ & $-1082 \mathrm{~A}>\mathrm{G}$ and $-509 \mathrm{C}>\mathrm{T}$ & $\begin{array}{l}\text { The frequency of rare alleles (the } \\
\text { CT or TT genotype of TGF- } \beta 1 \text { ) } \\
509 \mathrm{C} / \mathrm{T} \text { and AG or GG genotype } \\
\text { of (IL-10) } 1082 \mathrm{~A} / \mathrm{G} \text { was } \\
\text { significantly higher in AERD and } \\
\text { - } 1082 \mathrm{G} \text { had higher promoter } \\
\text { activity }\end{array}$ & $\begin{array}{l}\text { Alteration in IL- } 10 \text { production } \\
\text { caused by the }-1082 \mathrm{~A} / \mathrm{G} \text { in IL- } 10 \\
\text { may contribute to disease } \\
\text { pathogenesis which is } \\
\text { strengthened by a genetic } \\
\text { interaction with TGF- } \beta 1 \text {. }\end{array}$ \\
\hline ACE & $-262 \mathrm{~A}>\mathrm{T},-115 \mathrm{~T}>\mathrm{C}$ & $\begin{array}{l}\text { The frequencies of the rare alleles } \\
\text { were higher in AERD - } 262 \mathrm{~T} \text { had } \\
\text { lower promoter activity and fall } \\
\text { of FEV1 after aspirin provocation }\end{array}$ & $\begin{array}{l}\text { Downregulation of ACE } \\
\text { expression }\end{array}$ \\
\hline
\end{tabular}


TABle 1: Continued.

\begin{tabular}{|c|c|c|c|}
\hline Gene name & SNPs & Clinical phenotype & Mechanism \\
\hline KIF3A & rs 3756775 & $\begin{array}{l}\text { Fall of FEV1 and higher mRNA } \\
\text { expression of KIF3A in the ASA } \\
\text { induced bronchial epithelial cells } \\
\text { and protein expression in nasal } \\
\text { polyp epithelia in AERD }\end{array}$ & $\begin{array}{l}\text { Abnormality of cilia } \\
\text { predisposing to AERD }\end{array}$ \\
\hline SLC6A12 & rs499368, rs557881 & $\begin{array}{l}\text { The minor allele frequencies } \\
\text { were higher in AERD and fall of } \\
\text { FEV1 after aspirin provocation }\end{array}$ & $\begin{array}{l}\text { GABA signaling pathway in the } \\
\text { airway epithelium may play a } \\
\text { role }\end{array}$ \\
\hline CEP68 & $7572857 \mathrm{G}>\mathrm{A}$ & $\begin{array}{l}\text { Fall of FEV1 after aspirin } \\
\text { provocation by A allele }\end{array}$ & $\begin{array}{l}\text { Change in polarity of the protein } \\
\text { structure due to nonsynonymous } \\
\text { SNP which replaces Gly with Ser }\end{array}$ \\
\hline
\end{tabular}

IL13: interleukin 13, CCR3: chemokine receptor 3, CRTH2: chemoattractant receptor, IL10: interleukin 10, TGF: transforming growth factor, MS4A2R: high affinity immunoglobulin epsilon receptor beta-subunit (FcERI) TBXA2R: thromboxane receptor, CysLTR1: cysteinyl leukotriene 1, CysLTR2: cysteinyl leukotriene 2, ALOX5: arachidonate 5 lipoxygenase, HLA: human leukocyte antigen, LTC4S: leukotriene C4, ACE: angiotensin-converting enzyme KIF3A: kinesin family number 2A, SLC22A2: solute carrier family 6, CEP68: centrosomal protein, PTGER: prostanoid gene, TEC: total eosinophilic count, TF: transcription factor, MAZ: myc-associated zinc finger protein, SEA: Staphylococcus enterotoxin A, $\mathrm{FEV}_{1}$ : forced expiratory volume in $1 \mathrm{~s}$, AERD: aspirinexacerbated respiratory disease.

hypomethylated whereas PTGES was hypermethylated [41]. The calcium channel voltage-dependent gamma subunit 6 (CACNG6) gene encodes a protein that stabilizes the calcium channel. CACNG6 has been studied in AERD, which revealed that rs192808C > T may be associated with the risk of AERD in a Korean population [42].

2.6. AERD and Genome-Wide Studies. Genome-wide association studies (GWAS) have recently emerged as a technology that can predict genetic variations across the genome associated with human diseases and clinical responses to drug treatment. Recently, GWAS for asthma and related phenotypes have reported several susceptible genes. Candidate gene approaches have been used for most of the genetic association studies of AERD. GWAS suggested that the nonsynonymous CEP68 rs $7572857 \mathrm{G}>\mathrm{A}$ variant, replacing glycine with serine, showed a higher decline in $\mathrm{FEV}_{1}$ due to aspirin provocation than other variants and could be a susceptible gene for AERD. Gly74Ser could also affect the polarity of the protein structure [43].

2.7. Gene-Gene Interactions. Gene-gene interactions have also been proposed in the pathogenesis of AERD, and a few studies indicated that the genetic effects of CysLTs and LTC4S $-444 \mathrm{~A}>\mathrm{C}$ synthesis increased the lower level of $\mathrm{FEV}_{1}$ after lysine ASA inhalation [18]. TBXA2R 795T > C polymorphism was associated with HLA DPB1*0301 in AERD patients compared with ATA [23]. Recently, a synergistic effect between the TGF-beta1-509C/T and IL-10$1082 \mathrm{~A} / \mathrm{G}$ polymorphisms on the phenotype of AERD was noted when stratified by the presence of rhinosinusitis [44]. Moreover, Kim et al. reported a significant epistatic effect with a four-locus genetic interaction in the susceptibility to aspirin intolerance in asthmatic patients. This model includes four SNPs: B2ADR -46A > G, CCR3 - 520T > G, CysLTR1 -634C > T, and FCER1B - 109T > C [45]. These findings should be validated further in other cohorts.

\section{Conclusions}

AERD often produces a moderate-to-severe phenotype; however, diagnosis in these patients is challenging despite the availability of various techniques. A hypothesis has been put forward, mostly focused on the overproduction of CysLTs and arachidonic acid pathways. Most of the genetic studies have been performed using techniques such as GWAS and the candidate gene approach. However, replication studies in different ethnic groups will be essential to validate the reported data and apply this knowledge in clinical practice. Future areas of investigation should focus on identification of biomarkers for early diagnosis with various diagnostic techniques. These genetic studies will be able to extend our understanding about the molecular genetic mechanism of AERD and to find a genetic marker for predicting drug responses or hypersensitivity reactions. Furthermore, this will be helpful for the determination of new diagnostic tools and therapeutic interventions.

\section{Acknowledgment}

This study was supported by the Korean Science and Engineering Foundation (KOSEF) Grant funded by the Korean Government (MEST, 2009-0078646).

\section{References}

[1] A. Szczeklik, E. Nizankowska, and M. Duplaga, "Natural history of aspirin-induced asthma. AIANE Investigators. European Network on Aspirin-Induced Asthma," European Respiratory Journal, vol. 16, pp. 432-436, 2000.

[2] A. Szczeklik and D. D. Stevenson, "Aspirin-induced asthma: advances in pathogenesis, diagnosis, and management," Journal of Allergy and Clinical Immunology, vol. 111, no. 5, pp. 913921, 2003.

[3] N. S. Palikhe, J. H. Kim, and H. S. Park, "Update on recent advances in the management of aspirin exacerbated 
respiratory disease," Yonsei Medical Journal, vol. 50, no. 6, pp. 744-750, 2009.

[4] C. Picado, "Aspirin-intolerant asthma: role of cyclo-oxygenase enzymes," Allergy, vol. 57, no. 72, pp. 58-60, 2002.

[5] G. Çelik, S. Bavbek, Z. Misirligil, and M. Melli, "Release of cysteinyl leukotrienes with aspirin stimulation and the effect of prostaglandin E2 on this release from peripheral blood leucocytes in aspirin-induced asthmatic patients," Clinical and Experimental Allergy, vol. 31, no. 10, pp. 1615-1622, 2001.

[6] C. Chavis, I. Vachier, P. Godard, J. Bousquet, and P. Chanez, "Lipoxins and other arachidonate derived mediators in bronchial asthma," Thorax, vol. 55, no. 2, pp. S38-S41, 2000.

[7] Y. Hui and C. D. Funk, "Cysteinyl leukotriene receptors," Biochemical Pharmacology, vol. 64, no. 11, pp. 1549-1557, 2002.

[8] V. Capra, "Molecular and functional aspects of human cysteinyl leukotriene receptors," Pharmacological Research, vol. 50, no. 1, pp. 1-11, 2004.

[9] P. Ciana, M. Fumagalli, M. L. Trincavelli et al., "The orphan receptor GPR17 identified as a new dual uracil nucleotides/ cysteinyl-leukotrienes receptor," EMBO Journal, vol. 25, no. 19, pp. 4615-4627, 2006.

[10] C. Parravicini, G. Ranghino, M. P. Abbracchio, and P. Fantucci, "GPR17: molecular modeling and dynamics studies of the 3-D structure and purinergic ligand binding features in comparison with $\mathrm{P} 2 \mathrm{Y}$ receptors," BMC Bioinformatics, vol. 9, article no. 263, 2008.

[11] A. R. Sousa, A. Parikh, G. Scadding, C. J. Corrigan, and T. H. Lee, "Leukotriene-receptor expression on nasal mucosal inflammatory cells in aspirin-sensitive rhinosinusitis," New England Journal of Medicine, vol. 347, no. 19, pp. 1493-1499, 2002.

[12] M. Sanak, M. Pierzchalska, S. Bazan-Socha, and A. Szczeklik, "Enhanced expression of the leukotriene C4 synthase due to overactive transcription of an allelic variant associated with aspirin-intolerant asthma," American Journal of Respiratory Cell and Molecular Biology, vol. 23, no. 3, pp. 290-296, 2000.

[13] Y. Kawagishi, H. Mita, M. Taniguchi et al., "Leukotriene C4 synthase promoter polymorphism in Japanese patients with aspirin-induced asthma," Journal of Allergy and Clinical Immunology, vol. 109, no. 6, pp. 936-942, 2002.

[14] R. Van Sambeek, D. D. Stevenson, M. Baldasaro et al., " 5 ' Flanking region polymorphism of the gene encoding leukotriene C4 synthase does not correlate with the aspirinintolerant asthma phenotype in the United States," Journal of Allergy and Clinical Immunology, vol. 106, no. 1 I, pp. 72-76, 2000.

[15] J. H. Choi, S. H. Kim, J. S. Bae et al., "Lack of an association between a newly identified promoter polymorphism $(-1702 \mathrm{G}>\mathrm{A})$ of the leukotriene C4 synthase gene and aspirin-intolerant asthma in a Korean population," Tohoku Journal of Experimental Medicine, vol. 208, no. 1, pp. 49-56, 2005.

[16] J. H. Choi, H. S. Park, H. B. Oh et al., "Leukotriene-related gene polymorphisms in ASA-intolerant asthma: an association with a haplotype of 5-lipoxygenase," Human Genetics, vol. 114, no. 4, pp. 337-344, 2004.

[17] S. H. Kim, J. M. Oh, Y. S. Kim et al., "Cysteinyl leukotriene receptor 1 promoter polymorphism is associated with aspirinintolerant asthma in males," Clinical and Experimental Allergy, vol. 36, no. 4, pp. 433-439, 2006.

[18] J. S. Park, H. S. Chang, C. S. Park et al., "Association analysis of cysteinyl-leukotriene receptor 2 (CYSLTR2) polymorphisms with aspirin intolerance in asthmatics," Pharmacogenetics and Genomics, vol. 15, no. 7, pp. 483-492, 2005.

[19] C. Picado, J. C. Fernandez-Morata, M. Juan et al., "Cyclooxygenase-2 mRNA is downexpressed in nasal polyps from aspirin- sensitive asthmatics," American Journal of Respiratory and Critical Care Medicine, vol. 160, no. 1, pp. 291-296, 1999.

[20] M. L. Kowalski, R. Pawliczak, J. Wozniak et al., "Differential metabolism of arachidonic acid in nasal polyp epithelial cells cultured from aspirin-sensitive and aspirin-tolerant patients," American Journal of Respiratory and Critical Care Medicine, vol. 161, no. 2 I, pp. 391-398, 2000.

[21] L. S. Chambers, J. L. Black, Q. Ge et al., "PAR-2 activation, PGE2, and COX-2 in human asthmatic and nonasthmatic airway smooth muscle cells," American Journal of PhysiologyLung Cellular and Molecular Physiology, vol. 285, no. 3, pp. L619-L627, 2003.

[22] S. H. Kim, Y. K. Kim, H. W. Park et al., "Association between polymorphisms in prostanoid receptor genes and aspirinintolerant asthma," Pharmacogenetics and Genomics, vol. 17, no. 4, pp. 295-304, 2007.

[23] S. H. Kim, J. H. Choi, H. S. Park et al., "Association of thromboxane A2 receptor gene polymorphism with the phenotype of acetyl salicylic acid-intolerant asthma," Clinical and Experimental Allergy, vol. 35, no. 5, pp. 585-590, 2005.

[24] N. Jinnai, T. Sakagami, T. Sekigawa et al., "Polymorphisms in the prostaglandin E2 receptor subtype 2 gene confer susceptibility to aspirin-intolerant asthma: a candidate gene approach," Human Molecular Genetics, vol. 13, no. 24, pp. 3203-3217, 2004.

[25] B. L. Park, S. M. Park, J. S. Park et al., "Association of PTGER gene family polymorphisms with aspirin intolerant asthma in Korean asthmatics," BMB Reports, vol. 43, no. 6, pp. 445-449, 2010.

[26] J. H. Choi, K. W. Lee, H. B. Oh et al., "HLa association in aspirin-intolerant asthma: $\mathrm{DPB} 1^{*} 0301$ as a strong marker in a Korean population," Journal of Allergy and Clinical Immunology, vol. 113, no. 3, pp. 562-564, 2004.

[27] J. W. Dekker, E. Nizankowska, M. Schmitz-Schumann et al., "Aspirin-induced asthma and HLA-DRB1 and HLA-DPB1 genotypes," Clinical and Experimental Allergy, vol. 27, no. 5, pp. 574-577, 1997.

[28] S. Nasser, P. E. Christie, R. Pfister et al., "Effect of endobronchial aspirin challenge on inflammatory cells in bronchial biopsy samples from aspirin-sensitive asthmatic subjects," Thorax, vol. 51, no. 1, pp. 64-70, 1996.

[29] S. M. S. Nasser, R. Pfister, P. E. Christie et al., "Inflammatory cell populations in bronchial biopsies from aspirin-sensitive asthmatic subjects," American Journal of Respiratory and Critical Care Medicine, vol. 153, no. 1, pp. 90-96, 1996.

[30] N. S. Palikhe, S. H. Kim, B. Y. Cho, Y. M. Ye, G. S. Choi, and H. S. Park, "Genetic variability in CRTH2 polymorphism increases eotaxin-2 levels in patients with aspirin exacerbated respiratory disease," Allergy, vol. 65, no. 3, pp. 338-346, 2010.

[31] S. H. Kim, E. M. Yang, H. N. Lee, G. S. Choi, Y. M. Ye, and H. S. Park, "Association of the CCR3 gene polymorphism with aspirin exacerbated respiratory disease," Respiratory Medicine, vol. 104, no. 5, pp. 626-632, 2010.

[32] N. S. Palikhe, S. H. Kim, B. Y. Cho et al., "IL-13 gene polymorphisms are associated with rhinosinusitis and eosinophilic inflammation in aspirin intolerant asthma," Allergy, Asthma and Immunology Research, vol. 2, no. 2, pp. 134-140, 2010.

[33] A. Szczeklik, "Aspirin-induced asthma as a viral disease," Clinical Allergy, vol. 18, no. 1, pp. 15-20, 1988. 
[34] L. S. Van Rijt, C. H. Geurts Van Kessel, I. Boogaard, and B. N. Lambrecht, "Respiratory viral infections and asthma pathogenesis: a critical role for dendritic cells?" Journal of Clinical Virology, vol. 34, no. 3, pp. 161-169, 2005.

[35] S. Yoshida, H. Sakamoto, Y. Yamawaki et al., "Effect of acyclovir on bronchoconstriction and urinary leukotriene E4 excretion in aspirin-induced asthma," Journal of Allergy and Clinical Immunology, vol. 102, no. 6, pp. 909-914, 1998.

[36] A. Szczeklik, M. Schmitz-Schumann, E. Nizankowska, M. Milewski, F. Roehlig, and C. Virchow, "Altered distribution of IgG subclasses in aspirin-induced asthma: high IgG4, low IgG1," Clinical and Experimental Allergy, vol. 22, no. 2, pp. 283-287, 1992.

[37] E. Filipowicz and M. Sanak, "Exacerbation of aspirin-induced asthma associated with RSV infection," Przeglad lekarski, vol. 60, no. 3, pp. 185-187, 2003.

[38] N. S. Palikhe, S. -H. Kim, J. -H. Kim, P. Losol, Y. -M. Ye, and H. -S. Park, "Role of Toll-like receptor 3 variants in aspirin-exacerbated respiratory disease," Allergy, Asthma and Immunology Research, vol. 3, no. 2, pp. 123-127, 2011.

[39] J. S. Lee, J. H. Kim, J. S. Bae et al., "Association analysis of UBE3C polymorphisms in Korean aspirin-intolerant asthmatic patients," Annals of Allergy, Asthma and Immunology, vol. 105 , no. 4, pp. 307-312, 2010.

[40] J. H. Kim, J. Y. Cha, H. S. Cheong et al., "KIF3A, a Cilia Structural Gene on Chromosome 5q31, and Its Polymorphisms Show an Association with Aspirin Hypersensitivity in Asthma," Journal of Clinical Immunology, pp. 1-10, 2010.

[41] H. S. Cheong, S. M. Park, M. O. Kim et al., "Genomewide methylation profile of nasal polyps: relation to aspirin hypersensitivity in asthmatics," Allergy, vol. 66, no. 5, pp. 637644, 2011.

[42] J. S. Lee, J. H. Kim, J. S. Bae et al., "Association of CACNG6 polymorphisms with aspirin-intolerance asthmatics in a Korean population," BMC Medical Genetics, vol. 11, no. 1, article no. 138, 2010.

[43] J. H. Kim, B. L. Park, H. S. Cheong et al., "Genome-wide and follow-up studies identify CEP68 gene variants associated with risk of aspirin-intolerant asthma," PLoS ONE, vol. 5, no. 11, Article ID e13818, 2010.

[44] S. H. Kim, E. M. Yang, H. N. Lee, B. Y. Cho, Y. M. Ye, and H. S. Park, "Combined effect of IL-10 and TGF- $\beta 1$ promoter polymorphisms as a risk factor for aspirin-intolerant asthma and rhinosinusitis," Allergy, vol. 64, no. 8, pp. 1221-1225, 2009.

[45] S. H. Kim, H. H. Jeong, B. Y. Cho et al., "Association of four-locus gene interaction with aspirin-intolerant asthma in Korean asthmatics," Journal of Clinical Immunology, vol. 28, no. 4, pp. 336-342, 2008. 


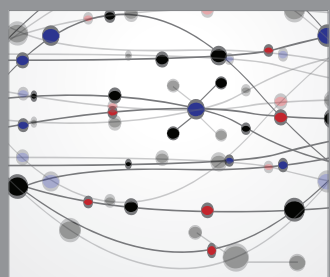

The Scientific World Journal
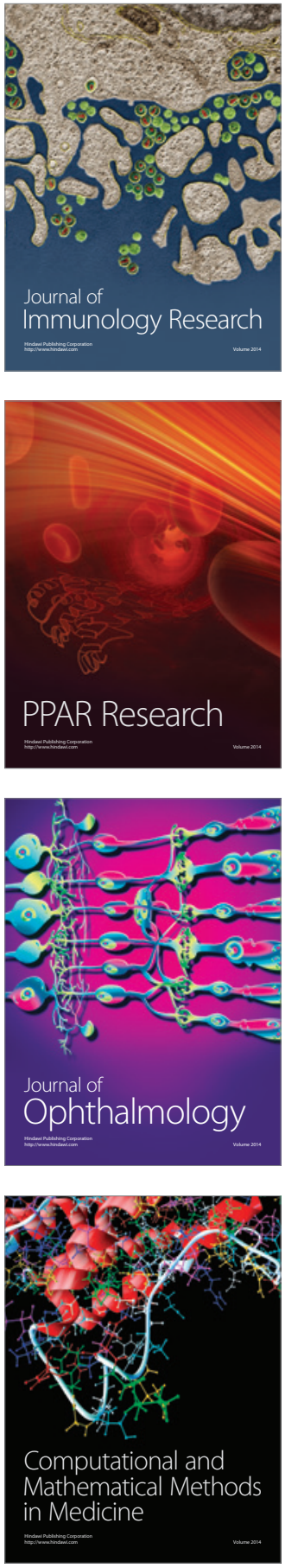

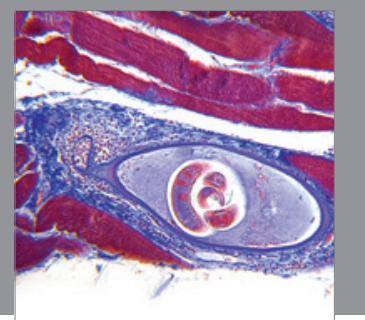

Gastroenterology

Research and Practice
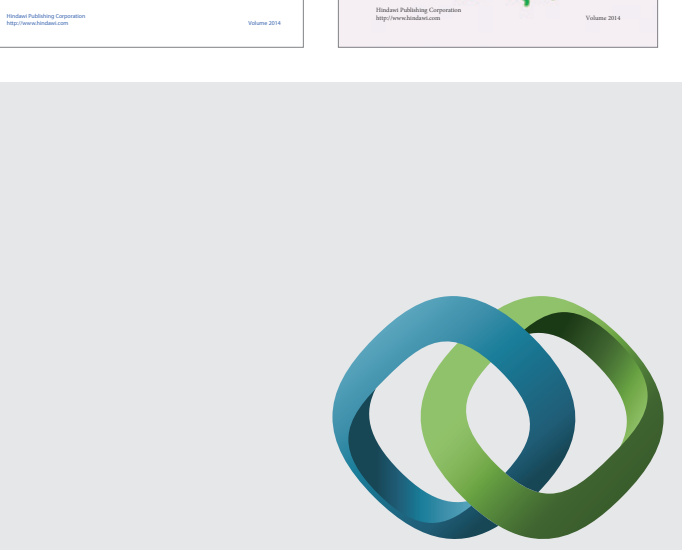

\section{Hindawi}

Submit your manuscripts at

http://www.hindawi.com
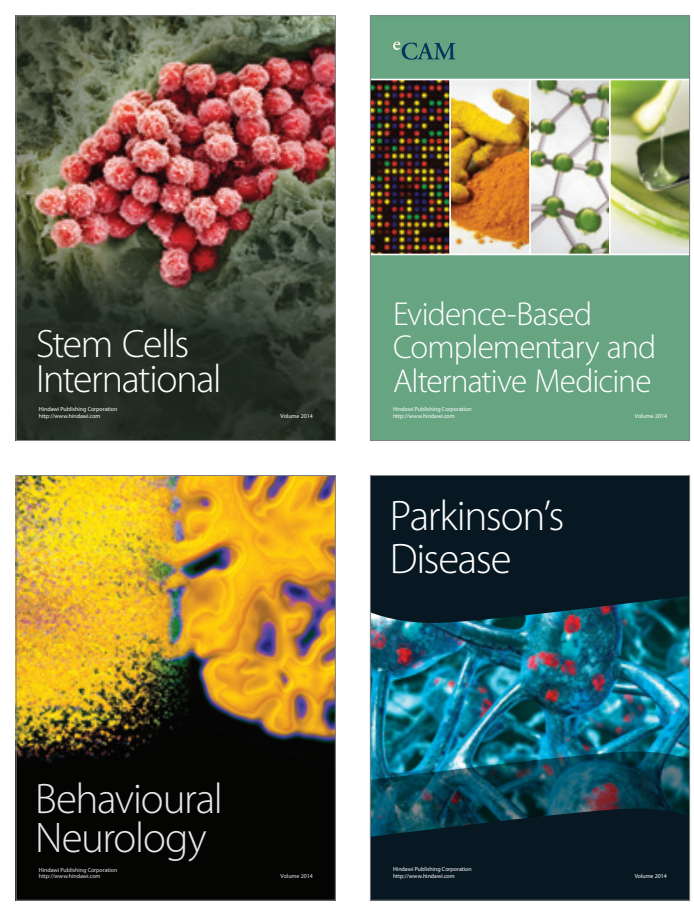

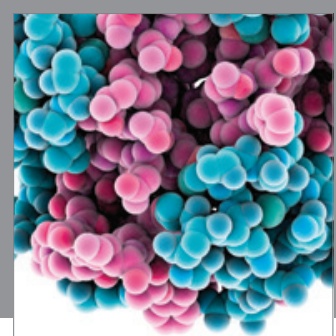

Journal of
Diabetes Research

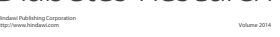

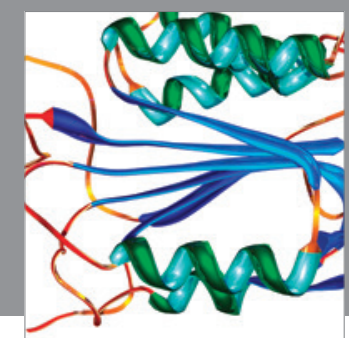

Disease Markers
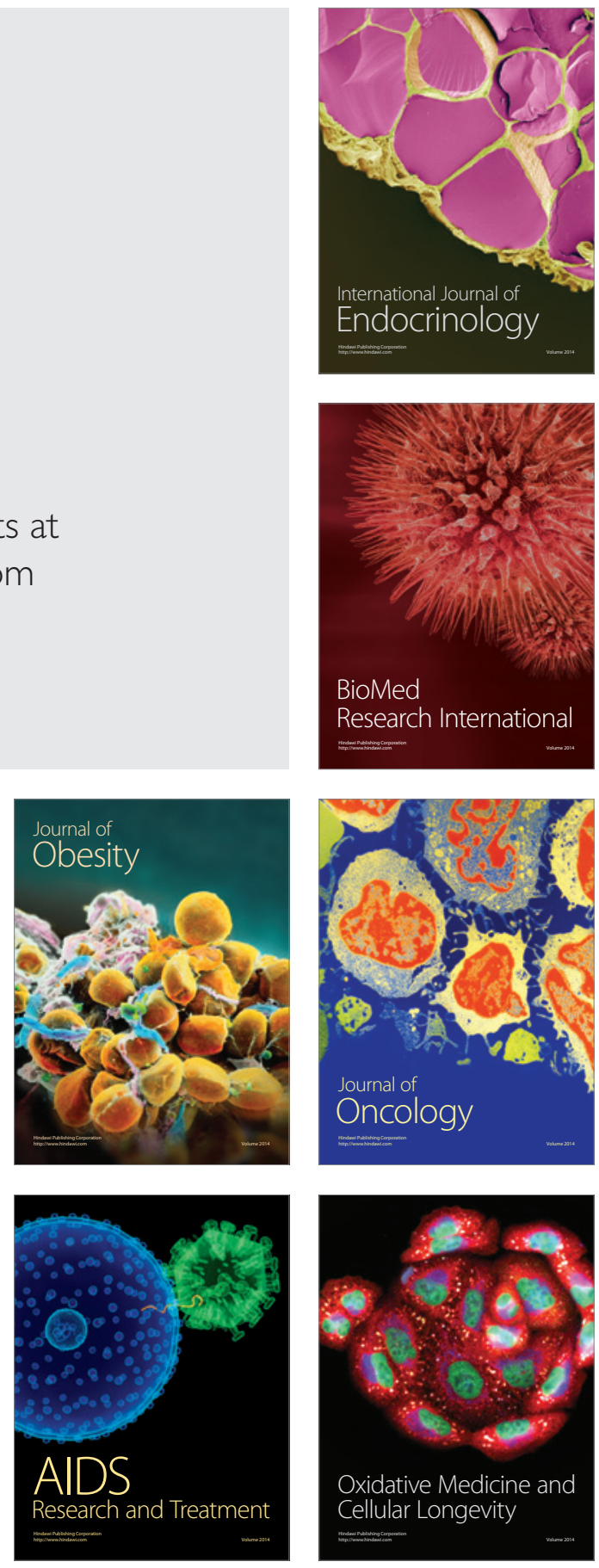